\title{
Contract System Pertaining to the Employment of Chief Directors in the Public Service in Ghana
}

This chapter examines the second country case study - Ghana. It looks at how the contract system regarding the employment of chief directors in the public service has operated in Ghana. The chapter starts with an overview of public service reform and the introduction of contract of employment and performance agreement. It also investigates the management approaches adopted in the reform and used in the contract system. The remaining sections of the chapter look at the entitlement to benefits under performance agreements, such as remuneration and pension, the scope of and potential for expression of leadership by the permanent secretary/chief director under contract, as well as how the contract system impinges on the independence and influence of the permanent secretary/chief director. It also considers how conflict is mediated in the evolving contract system of employment, the value-formoney of the new contract system of employment and, finally, the lessons that can be learned from the experience of the contract system.

\section{Overview of public service reform and introduction of contract of employment and performance agreement}

In Ghana the Public Services Commission (PSC) is the constitutional body that has been given the responsibility to make appointments, enact procedures and advise the government on conditions of service for the public sector, especially the civil service. Under First, Second and Third Republican Constitutions, the head of state had important powers of appointment, for example the appointment of judges and senior public servants, but these appointments were to be made in consultation with the PSC. Under the Fourth Republican Constitution of 1992, the executive president is the appointing authority of the chief directors - the principal secretaries until 1990, when the Provisional National Defence Council (PNDC) under Jerry John Rawlings changed the title and focus of the senior public service post. This came at the tail end of the revolution and Rawlings wanted to make a departure with the past. The President appoints chief directors in consultation with the Public Services Commission and the Civil Service Council. A panel of five distinguished individuals 
will normally sit and advise and then the Civil Service Council will convey the advice to the president for appointment. In the same way, for dismissals, the appointing authority could move and then three months' notice will be given to the chief director, within which time a committee is set up to look into the case.

The first set of chief directors (CDs) was expected to have 15 years of experience in the public service to be eligible and to hold, at least, a bachelor's degree. The existing seven principal secretaries did not apply for the post and only a few people from outside the service applied in 1992. The government was compelled to bring back the old principal secretaries in 1993. From the other applicants, 15 were appointed at the end of the interview, and two of them were from the Ghana Institute of Management and Public Administration (GIMPA), four came from outside the civil service.

According to the Head of the Civil Service (HOCS), Joe Issachar, the post of chief director is higher than the former principal secretary. The Civil Service Law 1993 (PNDC Law 327) was enacted to consolidate the reforms of the public service and it crystallised the post of chief director. The law clarified the structure of administration of the ministry and chief director was now supported by four directors in key competency and business areas of the ministry namely human resources directorate, finance directorate, policy planning directorate and information directorate. Out of the 27 ministries, only 15 had chief directors and this posed a serious problem to public management because the ten regions were also expected to be headed by chief directors.

In all, the structure of public administration in Ghana required 38 chief directors, but it was proving difficult to appoint the full complement and retain them. Until recently Ghana never had more than 15 chief directors serving and confirmed. In 2006 the Government of Ghana managed to appoint 37 chief directors for the regions and the centre.

One underlying reason for this seeming ambiguity could be traced to the fact that the government did not know how to treat the post of chief director. There is a debate going on regarding name change for the post and how to formalise its conditions of service. For instance, there were a number of ministries and regions managed by senior directors for well over the stipulated six months by which an acting chief director should be confirmed, and this had implications for morale and ultimately, productivity. The question was, if these senior directors were good enough to be retained in the post of acting chief director for that long, then what could have prevented them from being confirmed as substantive chief directors?

\section{Management approaches adopted in the reform and used in the contract system}

The general trend in administrative reform in Ghana seems to be in the direction of (1) reorganisation and structural changes in the government, as well as 
(2) harnessing of human resources for meaningful use in the public services through appropriate training, 'localisation' and incentive programmes. There were sustained reforms between 1982 and 1992. Three phases of administrative reform could be distinguished.

- The first phase was associated with Economic Reform Programme (ERP) 1 (1983-1986), the period of stabilisation and recovery of the economy after a near collapse in 1982 when inflation rose to 123 per cent.

- The second phase was associated with ERP 2 (1987-1990) related to the adjustment phase. A number of structural and institutional reforms were launched during this phase including pay reform. A Civil Service Reform Programme (CSRP) started in 1987 which had a focus on capacity building, including appropriate compensation to increase morale and work effort in the delivery of services. It also included employment reform, for which purpose three census of civil service employment were undertaken in 1986 and 1988. As a sequel, a retrenchment target of 15,000 per year for three years (1987-1990) was instituted and almost achieved ( 75 per cent), with the retrenchment being extended to 1992 . It is reported that in 1983 Ghana had more than 300,000 civil servants serving a population of 12 million.

- Finally, under ERP 3 (1993 onwards and the post-military period under the Fourth Republic), dubbed the 'accelerated growth' phase, the reforms involved sustainable development and alleviation initiatives, which were accompanied by enhancement of social services, human resource development and management capacity building in the public as well as private sector. ${ }^{1}$

Aside from the retrenchment, a selective recruitment freeze was instituted to allow for recruitment of critical skills while preventing overstaffed lower level occupational categories. Other components of the programme of improvement of the service included a review of the civil service management functions and the Civil Service Act and Administrative Instructions; full-scale review of salaries policy and grading; review of the Management Services Division, with a view to strengthening it; functional review and redeployment study, and training and staff development policy. ${ }^{2}$ The reformist agenda also saw the commencement of the Civil Service Performance Improvement Programme (CSPIP) in 1996 and the first phase was completed in 2001. This was followed by two interim phases up until 2003. Implementation of the CSPIP placed considerable emphasis on an agenda for 'home grown' management and a participatory approach to change management. All this was in response to the quest for country ownership which was taking root in international development from the latter part of the 1980s. As such, the original design of CSPIP contained two innovations: (i) the provision of Performance Improvement Facility (the rationale of which was not always clear), and (ii) the payment of incentives to the CSPIP Team. It is reported that concerns were raised about the fact that incentives were paid on an input rather an outcome basis. ${ }^{3}$ 
There was some confusion associated with the status of the chief director in at the beginning of the Fourth Republic in 1993. An emerging consensus around that time was that the chief director should come in with the government of the day and leave with the government when it is voted out of office. This did very little to inspire confidence and so resulted in a difficulty to fill the posts and have a full complement of chief directors. The essence of the debate was whether the chief director's post was to be career or political, and questions were raised about impartiality, loyalty and professionalism in the public service. This uncertainty led to some directors serving for as much as six years as chief directors without being confirmed. It was not until 2005 that the chief directors' posts were advertised in the newspapers and interviews were conducted and appointments made in 2006. In that year almost the full complement of chief directors was in place and only three were not career civil servants. ${ }^{4} \mathrm{~A}$ list of chief directors at post as at 1 August 2008 showed that there were 33 of them. ${ }^{5}$ Table 2 shows the age range of the chief directors.

Table 2. Age of chief directors in Ghana

\begin{tabular}{cc}
\hline Age range (on 1 August 2008) & Number \\
\hline $50-54$ & 4 \\
$55-60$ & 21 \\
$61-65$ & 7 \\
TOTAL & 32 \\
\hline
\end{tabular}

Note: There was no information on the age of one chief director, but that person was on contract employment.

Table 3 shows the employment status of 33 chief directors in Ghana. The list secured from the Office of the Head of the Civil Service showed that there were three types of status of appointment - normal (i.e. open tenure), contract and limited engagement.

Table 3. Contract status of chief directors in Ghana

\begin{tabular}{lc}
\hline Status of appointment (on 1 August 2008) & Number \\
\hline Normal & 22 \\
Contract & 8 \\
Limited engagement & 3 \\
TOTAL & 33 \\
\hline
\end{tabular}

Note: The chief directors who are on 'limited engagement' are not regular civil servants. 
In 1997 and 1999 the government introduced a performance agreement system for chief directors and deputy directors and heads of department, respectively, to address the problem of compression and inability of government to raise pay substantially for all. This was in spite of the Ghana Universal Salary Structure (GUSS) review of 1999. The performance agreement is made between the Government of Ghana and the chief director.

Two main reasons have been given for the establishment of the performance agreement. First, the idea of the agreement was to ensure achievement of public policy objectives under the Ghana Poverty Reduction Strategy II. Secondly, there was a need to benchmark the performance of the chief directors, and the performance agreement was seen as the way in which this could achieved. The performance agreement covers four objectives that must be achieved. These include:

- Preparation of the budget by a certain stipulated date,

- An annual report which must be ready by June of the ensuing financial year (in Ghana, the financial year is from January to December),

- That the chief director will ensure staff development,

- Prompt responses to audit queries, and

- Financial propriety.

In addition to this, there are certain deliverables that are peculiar to each ministry. The performance agreement is signed by the chief director, countersigned by the responsible minister and the Head of the Civil Service (HOCS). A review mechanism has been instituted to monitor performance. It includes two institutional players, namely, the Head of the Civil Service and the Civil Service Council. The HOCS and the Civil Service Council are charged with the responsibility to set up the review pan$\mathrm{el}$, and the latter determines who sits on the evaluation panel. The initial panel or review committee consisted of three members, which includes the Director General of the Ghana Institute of Management and Public Administration or someone related to that institute, and a former cabinet secretary. It should be noted that the first review was done in 1998, followed by a second in 2000 . However, since that time the review has been irregular and this has affected evaluation of the experiment.

Four issues emerge from the assessment of the evaluation system associated with the performance agreement. The first is that the expected rewards and sanctions system to accompany the new performance agreement is yet to be laid out. Secondly, there is the issue of cascading, which is related to the fact that the chief directors were busy and did not get their directors to sign the performance agreement that expected to be signed between the chief director and the directors. In the interview, it was revealed that some of the chief directors were not conversant with the performance agreement and were therefore unable to administer it to their subordinates. Thirdly, there was no government position or policy on the new system, and the HOCS did 
not have the resources to reward and sanction the chief directors. Finally, the study also revealed that at the time the minister did not understand the system. The overall feeling emerging from the investigation is that ministers had not assumed policy ownership of the performance agreement.

This revelation calls for a revisitation of policy and institutionalisation process of the performance agreement. The HOCS noted that a remedial measure had been adopted in which a consultant had been employed to review the performance agreement system, and as part of that, a workshop was organised for the chief director. This was approved by the Civil Service Council and a further measure was instigated in the form of a Cabinet Memorandum. In the memorandum a 13th month salary or a bonus was proposed as a solution to the incentive question. At the individual level of performance, however, a performance facility was proposed, which includes the supply of computers.

\section{Entitlement to benefits under performance agreements: remuneration and pension}

Generally, the salary levels of public servants are low. The chief director's pay is approximately about US $\$ 1,000$ per month (net). The general perception of public servants is that the chief director should be the highest paid public officer. However, traditionally, the parastatals have been singled out of the public service and given better terms and conditions of service than the civil service. In the interviews and discussions for this study, it was alleged that this affects the relationship of the chief director with the heads of department (HODs) of the statutory bodies and parastatals. An ongoing pay and pensions reform known as the New Comprehensive Salary Structure Review, initiated by government in 2006, is expected to resolve some of these anomalies because the chief director is higher in rank and the HODs report to the former. The consultants are noted to have come up with a 'single-spine' pay structure to deal with the problem of disparate pay structure of parastatals and statutory bodies, as well as a 25-level grade structure which was developed for reclassifying all public sector jobs. The report had been submitted to Cabinet in July 2008, with options for consideration by the Government. There are 17 service commissions and it is said that each service had its own salary structure, thus making the management of public emoluments unwieldy. A Fair Wages and Salaries Commission was established by Act 737 (2007) which is responsible for bargaining with the labour unions to determine salaries in the public sector, including that of chief directors.

There are two types of pension in the public sector. The first one was handed down to the post-independence government by the colonial administration. It is commonly known as the Colonial Cap 30 Pension Scheme and it paid pensions on retirement of civil servants including the chief director. Gratuities were also paid accordingly. In 1972, however, the Social Security and National Insurance Trust (SSNIT) Decree instituted a SNNIT scheme based on level of salary. None of this is considered superior 
today. Cap 30 is considered as unsustainable, while the management of the SNNIT scheme has left much to be desired. A three-tier arrangement for pension was under way during August 2008, which was, first, to reform the SNNIT scheme; and secondly, to establish a contributory pension based on 5 per cent of gross salary, to be managed outside SNNIT. Thirdly, private discretionary schemes are to be encouraged to help improve workers' conditions after retirement. Article 199 of the Constitution of Ghana 1992 states that:

1. A public officer shall, except as otherwise provided in this Constitution, retire from the public service on attaining the age of 60 years.

2. A public officer may, except as otherwise provided in this Constitution, retire from the public service at any time after attaining the age of 45 years.

3. The pension payable to any person shall be exempt from tax.

The chief director also receives some in-kind benefits. This includes free housing, telephone, residential security personnel (a watchman), a houseboy, and a chauffeurdriven car with petrol supplied. The Ministry of Finance has also arranged for chief directors a bulk finance arrangement with the utilities. The national Comprehensive Salary Structure exercise has sought to monetise the non-cash benefits across the public service. This has sparked off a debate in the senior public service ranks about how to monetise some of the in-kind benefits and bring the salary levels of the chief director to about US $\$ 3,000$. However, there was no agreement on the acceptability of the proposal.

\section{The scope and potential for expression of leadership by the permanent secretary/chief director under contract}

With regard to issues related to the environmental conditions which impinge on the ability of the chief director to express leadership, the study revealed a number of factors. This includes the paucity of resources, lack of an adequately trained workforce, insufficient information and communications technology facilities. In terms of resources, it was revealed that the ministries, departments and agencies in Ghana were under-resourced. Budgets are reviewed and adjusted in the course of the year, signalling that financial autonomy is far from being achieved and this tends to initiate a culture of non-performance. Similarly, it was noted that in spite of the numerous capacity-building initiatives, the various administrations since the commencement of the Fourth Republic have inherited a backlog of untrained staff. The need for capacity became acute in 2006, from which time various training programmes have been organised for senior public service staff at GIMPA, the University of Ghana Business School, especially courses in policy delivery and management. As a rule, middle level civil servants receive their training from the Civil Service Training Centre. 


\section{How the contract system impinges on the independence and influence of the permanent secretary/chief director}

In Ghana the greatest factor which impinges on the independence of the chief director is the lack of adequate resources to carry out the requirements of administration. The chief director is also the accounting officer. It is unusual to find two chief directors in one ministry, as was the case in the Ministry of Foreign Affairs in the 1990s, when that ministry had four chief directors - one for the political and economic divisions, one for protocol, one for policy planning and one for administration. The lines of accountability are much clearer than before and the chief director responds to administrative queries from the Public Accounts Committee of Parliament related to probity, sound management and financial propriety.

\section{How conflict is mediated in the evolving contract system of employment}

Two scenarios were painted by the head of the Civil Service with regard to conflict resolution. The first is that there is a lot of trust and confidence between the minister and the chief director. In this scenario, very little conflict occurs. The second scenario borders on the margin of trust. In this scenario, mistrust ensues where the minister feels that the chief director has the competence, but where the chief director could misdirect the minister in policy matters. This scenario was thought to be plausible because there could be an issue of indiscretion. The overall assessment of conflict was that there had not been any separations of chief directors based on conflict with the minister.

Article 196 of the 1992 Constitution of Ghana states that 'The Public Service Commission shall have such powers and exercise such supervisory, regulatory and consultative functions as Parliament shall, by law, prescribe, including as may be applicable, the supervision and regulation of, entrance and promotion examinations, recruitment and appointment into or promotions within, the public services, and the establishment of standards and guidelines on the terms and conditions of employment in the public services'. Because of the provisions of Articles 199 and 196 of the 1992 Constitution (quoted above), and the processes through which the chief director is appointed, the post holder is a public officer and he/she enjoys the protections granted, including the human rights provisions in the Constitution. This therefore underlies the established rule of law and the chief director is unlikely to be dismissed arbitrarily without following proper procedure, as obtained under military rule or contemporary Zambia where a permanent secretary could be dismissed at a press conference before he/she knows about it or gets the dismissal letter. 


\section{Value for money of the new contract employment system}

At the current stage of implementation, the performance agreement and contract employment system in Ghana do not yet offer optimal value for money. Two chief directors among the officials who were interviewed for this study noted that, apart from citizens who need to receive the best of services, the public service has an obligation to the development partners who are supporting the Ghana Poverty Reduction Strategy II (GPRS II) through the multi-donor budget support (MDBS), as such performance contract and evaluation systems that are still missing from public management have to installed as a matter of urgency.

To obtain additional value for money for the investment that the country makes in the chief directors, the government has since 2006 enunciated a proposal to establish a senior public service (also called senior executive service in other Commonwealth countries). This senior public service (SPS) has been conceptualised to include managers of public services, chief directors and directors of civil service. Accordingly, a Senior Public Service Commission (SPSC) has been proposed which will be made up of the Head of the Civil Service, president of the Public Service Commission, president of the State Enterprises Commission, two members of the private sector and one member of the Civil Service Association. In the proposal, the members of the SPS would be graduates of a School for Public Leadership (SPL) at GIMPA and would have to apply to the SPS and pass an oral interview with the SPSC. Membership will be open to private sector middle managers (40 years old minimum) and civil servants with a minimum of 15 years' experience who are already graduates of the School of Public Administration at GIMPA. Purportedly, the establishment of the SPS will be to prevent parochialism in ministerial/departmental management, promote policy co-ordination between departments, and enhance professionalism and implementation of government policy by investing in people and promoting mobility and quality. ${ }^{6}$

Similarly, the government has initiated a policy on the development of service charters and this exercise is being developed by ministries and district assemblies and is being led by the chief director and the district co-ordinating director (DCD). Each organisation develops its own charter and the finished document is sent to the ministry of public sector reform for quality assurance and printing.

\section{What lessons can be learned from Ghana's experience of the contract systems?}

The study revealed that, in its public sector reform effort, Ghana has drawn lessons from new public management approaches to reform the terms and conditions of service of senior public servants. Ghana has a three-pronged approach to appointing its senior public servants, namely through contracts of employment, normal open tenure and a contract of service called 'limited engagement'. The senior public servant 
or chief director (called permanent secretary in other jurisdictions) also signs a performance agreement with the government of Ghana, but at present it does not have established performance measures and can therefore not be called a performance contract. In spite of their contractual status, all chief directors are public officers and they are entitled to a non-taxable pension at the end of their service. The biographical data showed that the chief director category is an ageing population. Twenty-eight (28) of the 32 chief directors are between 55 and 65 years. This indicates that it will be a propitious move for Ghana to speed up the implementation of the senior public service concept so that younger public servants of 40 years and above could receive the specialist leadership training envisaged, in order to avert a leadership crisis.

\section{Notes}

1. Government of Ghana, Public Service Commission (2008) 'History of Public Sector Reform in Ghana'. Policy Brief.

2. Ibid.

3. Ibid.

4. Interview with Chief Director, Office of the Head of the Civil Service, August 7, 2008.

5. 'List of Chief Directors - As at $1^{\text {st }}$ August 2008', supplied by the Head of the Civil Service, Accra, August 8, 2008.

6. Management Services Division, Office of the Head of the Civil Service (2006) 'A Senior Service Class for Ghana'. Brief. Accra, Ghana. 